Ocula ${ }^{16}$

Semiotics of Economic Discourse

Semiotica del discorso economico

a cura di Giorgio Coratelli, Francesco Galofaro, Federico Montanari

www.ocula.it | Dicembre 2015 - DOI: 10.12977/ocula44

\title{
Ferruccio Rossi-Landi: \\ language, society and semiotics
}

\section{Cinzia Bianchi}

Department of Communication and Economics,

University of Modena and Reggio Emilia, Italy.

cinzia.bianchi@unimore.it

\begin{abstract}
The work of Ferruccio Rossi-Landi, which began in the fifties and ended in the mideighties, ranged through philosophy and linguistics to semiotics. My essay aims to provide a systematic presentation of the contribution of Rossi-Landi's work, taking into account the various theoretical stages that led him to conceive and study language from such an original point of view. Through his "homological schema", material and linguistic production are conceived to be the result of a single process that is particular to human beings and that can best be understood in terms of work and trade. The essay focuses particularly on the critical debate that surrounded Rossi-Landian theory, presenting some of the objections of the scholar's contemporaries together with his reactions to them, as well as touching on more recent interpretations.
\end{abstract}

\section{Keywords}

Rossi-Landi; Marxist semiotics; Homology; Social reproduction

\section{Summary}

1. Introduction

2. Studies in philosophy and linguistics

3. Constant and "fluid" elements in language

4. A priori in language and "mental work"

5. Marxist semiotics

6. A Marxist reading of Wittgenstein

7. The theory of homology

8. Metaphoric aspects of the theory

9. Linguistic peculiarities

10. Social reproduction

11. The role of sign systems

12. The mediation of semiotics

References 


\section{Ocula ${ }^{16}$}

Semiotics of Economic Discourse | Semiotica del discorso economico

Cinzia Bianchi | Ferruccio Rossi-Landi: language, society and semiotics

\section{Introduction}

This paper intends to provide a systematic presentation of the theoretical contribution of the work of Ferruccio Rossi-Landi (Milan 1921 - Trieste 1985), starting from his early studies in philosophy, pragmatics and linguistics through to his mature phase, commonly referred to as Marxist semiotics.

The decision to retrace his entire intellectual journey was made deliberately in the belief that his early work, and above all the reflections that Rossi-Landi himself later made on it, offer an indispensable key to understanding many developments of his later semiotic theory.

An essay on Rossi-Landi, thirty years after his death, could fall into one of two misapprehensions commonly found in the works dedicated to him, and that I consider equally misleading.

The first attitude is that of a scholar who initially perceives Rossi-Landi's work as naive, incomplete and in many ways lacking, only to discover after a careful analysis of the reasons leading to this criticism, that Rossi-Landi is actually held accountable for something that only emerged in later theory. This approach fails to take into account the historical development of ideas, considering them outside their historical context, as though it were possible to have (and debate) "pure" theory, removed from the cultural context that inevitably produced or affected it. The opposite approach tends rather to emphasize the brilliant foresight of theories expressed by Rossi-Landi many years earlier, and thus consider the scholar's work as a precursor to all later theory and an indisputable source of reference that remains beyond reproach.

Both approaches seem excessive and, in an attempt to avoid them, I will call upon the expertise and historical sensitivity of my readers. I will therefore describe Rossi-Landi's intellectual journey, leaving to my readers the consideration on how each subject area and theory studied by this scholar has evolved and changed in the meantime, for instance, how subsequent research has answered some of his questions, overcome some issues he raised or, simply, has placed the focus elsewhere.

From this point of view, I think it seems reasonable to retrace the different stages of his research, including those less known passages or others considered of secondary importance by the scholars who have been inspired by him over the years. I believe it is fundamental to follow the stages of this intellectual journey, as this highlights how he continuously assumed positions that he would later re-examine as well as raising questions and proposing answers that we should rightfully consider within their historical context to avoid trivializing his theory. This is why I wish to focus particularly on the criticisms of his contemporaries, to whom Rossi-Landi responded extensively and meticulously. However, I wish also to consider 


\section{Ocula ${ }^{16}$}

Semiotics of Economic Discourse | Semiotica del discorso economico

Cinzia Bianchi | Ferruccio Rossi-Landi: language, society and semiotics

the scholar's own thoughts on the earlier stages of his work and reflect on his awareness that the ideas he had previously proposed, though subsequently considered wrong or lacking, in fact contributed greatly to the formulation of his theory of language as work and trade, the crucial final stage of his Marxist semiotics.

\section{Studies in philosophy and linguistics}

The work Ferruccio Rossi-Landi started in the 1950s, ranges from semiotics to the philosophy of language. For a long time, Rossi-Landi was interested in the definition of cultural concepts and methodologies which were quite different from the philosophical investigations that characterised the Italian scene in the first half of the 2oth century. He translated Charles Morris' Foundations of the Theory of Signs, and wrote a study on this American author. He then translated The Concept of Mind by Gilbert Ryle, and published numerous papers on analytical philosophy. Moreover, he studied scholars like Giovanni Vailati, Eugenio Colorni and Mario Calderoni, devoting major attention to scientific and linguistic operationalism. ${ }^{1}$

Rossi-Landi's work in this area was extremely accurate, and yet he never considered himself a historian of ideas; his main interest remained theoretical, as he claimed at the 1984 Congress of the International Association for Semiotic Studies: "I have only written books and articles about problems" (1988: 1053). With a wealth of ideas and theoretical proposals, he advanced original points of view that not only anticipated, but truly foreshadowed, many contemporary ideas. It is important to understand this period of Rossi-Landi's work, and to try and identify some of the most relevant philosophical and semiotic problems it contained.

One significant aspect, for instance, is Rossi-Landi's discussion of the observationess of the sign. According to him, if one follows Morris -who maintained that semiotics was a biological science - one has to expand the analytical methods of biology to the field of signs and values. The problem with this procedure lies in the fact that normally such analytical methods focus on the actions performed by organisms as. By doing what Morris proposes, all sign behavior is thus reduced to observable behavior, and yet, according to Rossi-Landi, this method fails to include situations where behavior does not derive from sign and value activities. ${ }^{2}$ It is possible to overcome some problems arising from Morris' behaviorism by analyzing the mental operations that are common to every human being. One could, for instance, investigate the pragmatic act of the interpreter, and bear in mind that it is not possible to observe the property of "being a sign" in things, and

${ }^{1}$ For a concise introduction to Rossi-Landi's works, see Petrilli 1992: 1-5. See also Ponzio 1986, 1988a, 2008, 2012 and Bianchi 1995.

${ }^{2}$ See Rossi-Landi 1953a, 1954, 1967b, 1975c, 1975d, 1978d. For an analysis of the evolution of Rossi-Landi's reading of Morris, see, for instance, Petrilli 1987b and 1992. 


\section{Ocula ${ }^{16}$}

Semiotics of Economic Discourse | Semiotica del discorso economico

Cinzia Bianchi | Ferruccio Rossi-Landi: language, society and semiotics

at the same time assign fixed properties to those things themselves. The property of "being a sign", on the contrary, is a relational one that can be given to any object because of the relationship that each object has with the other objects: it is a property given by investiture. 3

Moreover, one could examine the problem of the communicative context, as well as the fact that it is difficult, if not impossible, to identify the meanings of a word or of a sentence without considering the context in which they appear. In Rossi-Landi's essays on the analytical philosophers, he agrees with their analyses of "linguistic uses", even though he considers their refusal to make any generalization as rather dogmatic. Rossi-Landi states that the importance of the analysis of examples and the accumulation of material does not escape "the one who considers the fact that traditional philosophical systems were built on categorial distinctions devoid of exemplifications; or the fact that they rested upon weak and naive examples, and would fall apart as soon as new exemplifications were offered". 4 The use of examples is a positive aspect of analytical philosophy only when it provides a strong refusal of any methodological principle, which is preconceived and persistently stated, while it becomes negative when precluding general considerations. 5

Another aspect of Rossi-Landi's early work regards the terminology of philosophical research. Rossi-Landi stated that, even though we are immersed in an intricate network of classifications and distinctions that none of us created, we have the freedom to accept or refuse them after establishing their adequacy to our goals. Thus, in philosophy it makes little sense to create new terminologies continuously, even though in some cases, it might be fruitful to use technical language in a parsimonious manner. ${ }^{6}$

3 This relational definition of sign is one of concepts studied by Silvio Ceccato and the other scholars of the "Italian Centre of Methodology and Language Analysis". Following the scientific research of Percy William Bridgman and Hugo Dingler, Ceccato tried to generalize the operative approach, directing his attention to the methodological analysis of language. However, he expressed reservations about some results and objectives of this approach to language, Rossi-Landi often acknowledged them. From 1949 to 1952, he was part of the editorial staff of Methodos, a journal that published the discussions of more Italian, German and American operationists. See Bridgman 1927; Dingler 1931 and 1936; Ceccato 1951; Rossi-Landi 1949, 1950, 1951, 1953b, 1961 (and particularly 1979d), 1987, 1988.

4 See Rossi-Landi 1955b: XIX. The translation is mine.

5 For this question, see Rossi-Landi 1961: 252 ff. For other considerations of analytical philosophy, see Rossi-Landi 1953c, 1953d, 1955b, 1955c, 1955d, 1955e, 1955f, 1956, 2003. See also Bianchi 1994, Caputo 2005 and Zonzella 2005.

${ }^{6}$ According to Rossi-Landi, the technical terms are excessively used both by Morris and Ceccato, while they have been refused (even when needed) by analytical philosophies. The investigation on philosophic terminology was encouraged by studies conducted by Giovanni Vailati and other Italian pragmatists at the beginning of the century, like Mario Calderoni, Eugenio Colorni, Federigo Enriques, Giuseppe Peano. These scholars, although different from one another, all detached themselves from a well defined tradition and, as scientists, have carried out "philosophical" studies on the fundamental principle of the various sciences. See Rossi-Landi 1952, 


\section{Ocula ${ }^{16}$}

Semiotics of Economic Discourse | Semiotica del discorso economico

Cinzia Bianchi | Ferruccio Rossi-Landi: language, society and semiotics

\section{Constant and "fluid" elements in language}

In 1961, Rossi-Landi wrote Significato, comunicazione e parlare comune [Meaning, Communication and Common Speech], a work that constitutes a theoretical synthesis of his early work on semiotic and philosophical problems. Here, Rossi-Landi proposes a new approach to the study of language. It is an attempt to "graft" certain logical and linguistic techniques particularly Wittgenstein's notions of linguistic games and families of concepts - onto the domain of non-idealistic European historicism (RossiLandi 1961: 20; 1983: 24-27). He studies the general conditions that make meaning and communication possible, starting from two philosophical traditions, "the Italian one, with its German and in general continental influence, and the British one, with its American extensions"(1961: 19).7 Rossi-Landi attempts to retain the most significant aspects of the two traditions and mitigate their extreme positions. More precisely, he tried "to give back to the British a sense of historicity absorbed from the Italian tradition, and to provide the Italian with some of the technical attention the British tradition displayed"(1961: 20).

Rossi-Landi's aim was to study "the a priori in language employing Kant's transcendental logic considered as an investigation de jure and not de facto"(1961: 19). To study the a priori in language does not mean adopting an aprioristic and deductive method. It is possible and necessary to find the a priori in language by starting with empirical research; that is, one can identify the constitutive operations that make meaning and communication possible without thinking of a normative and necessary universal capacity. It is a probable, imperfect and relative capability and the only possible a priori, at least in language.

In analyzing language, Rossi-Landi states that one cannot dwell only upon problems related to the communicative context, nor can one emphasize only what remains constant. On the contrary, one must look at both as well as studying how the linguistic units remain sufficiently constant during the transposition from one "universe of discourse" 8 to another, i.e. study their

1957d, 1957e, 1958c, 1966, 1967a, 1975a. On the relation between Rossi-Landi and Vailati, see Ponzio 1988a and 1988b.

${ }^{7}$ Significato, comunicazione e parlare comune has never been translated into English. Anything quoted from this source will be translated by me. Rossi-Landi refers to this book in 1968b, 1978b, 1983 (pp.24-27) and in 1990 (pp.71-75).

8 The Italian phrase "universo del discorso" used by Rossi-Landi, is very difficult to translate in English. As the translator of Ideology and Marxism states in his "Preface" (see Rossi-Landi, 1990: IX-X), the term "discourse" has a technical sense that the Italian term "discorso" does not necessarily have. Therefore, he considers the phrase "universe of discourse" as a strange expression in English and he has generally translated it as "a discourse". However, I prefer to utilize "universe of discourse" because Rossi-Landi uses the same expression of logical analysis in an enlarged and de-formalized manner. For the technical definition of "universe of discourse" see, for instance, Peter F. Strawson, 1952. For Rossi-Landi's definition, see also Rossi-Landi 1958 and 1958d. 


\section{Ocula ${ }^{16}$}

Semiotics of Economic Discourse | Semiotica del discorso economico

Cinzia Bianchi | Ferruccio Rossi-Landi: language, society and semiotics

"constancy" (permanenza). On the other hand, one ought also to investigate the extent to which the context is crucial in specific acts of communication, i.e. study the "fluidity" (fluenza) of such units.

In fact, fluidity and constancy of linguistic units are always "relative". This implies that there are some logical and linguistic elements that are altered by time less rapidly than others; they remain sufficiently constant and could be considered the same elements. This is what happens with common speech, i.e. with the set of concrete linguistic techniques through which language (langage) manifests itself. 9

While the term "language" (langage) highlights the general capacity to express thought, "speech" refers to the "stage which must be crossed when language as a whole manifests itself by means of and within a given language (langue)"(1961: 44). Such speech is "common" because it involves techniques that are intersubjective, collective, and thus, common to all speakers since it is through them that we communicate with one another.

If we maintain that common speech remains stable, beyond the many differences that exist between the various languages, it follows that the flow of its categories appears to be less important compared to those cases in which it is relatively rapid and historically traceable. Common speech is partly subject to continuous and yet slow variations due to the "changing of social and historical conditions (uses, belief, ideologies, philosophical thoughts) and influenced by technical and scientific progress" (1961: 166). As Rossi-Landi states elsewhere (1958d), concepts form themselves in history (or in prehistory) and one must always bear in mind that some of these concepts do not remain the same; they are "born" and they "die" without undergoing any change.

However, in a given situation and in a particular historical moment, these variations can be inconsistent in relation to our categorizations and our common speech. For current research, the a priori intersubjective characterizations of language are the only ones possible, and yet it may be that in the future others will become available.

\footnotetext{
9 The two Italian terms "linguaggio" and "lingua" are both equivalent to "language". Therefore, I have added in brackets the French terms "langage" and "langue" to explain which meaning is implied. Rossi-Landi's distinction between "thought", "language" (langage), "common speech" and "language" (langue) is very different from the opposition between langue and parole made by Saussure (see Saussure 1916). Both "language" (langage) and "common speech" are collective for various aspects, Rossi-Landi says. One could make a distinction between a "collective language" (langue) and "individual speech" (parole). However, Rossi-Landi states, "if speech (parole) is in fact individual, we must ask what it is that binds the innumerable individual "speeches" together, generating the system of the sentences that all speakers learn to produce univocally, and then the other and more complex systems as well"(Rossi-Landi 1983: 148). To understand the relationship between a language (langue) and a speech (parole), we must introduce the notion of "common speech" - which Rossi-Landi is going to interpret afterwards as "collective speech". See particularly Rossi-Landi 1983: 148 ff.
} 


\section{Ocula ${ }^{16}$}

Semiotics of Economic Discourse | Semiotica del discorso economico

Cinzia Bianchi | Ferruccio Rossi-Landi: language, society and semiotics

If it is undoubtedly necessary to recognize something that is constant in our language, the context can aid us in identifying the meaning of a word, a sentence or other "linguistic parts" (pezzi linguistici). In Significato, comunicazione e parlare comune, Rossi-Landi proposes a second avenue for research that deals with all those communicative situations in which context assumes a primary role. Such a critical investigation must begin from a fundamental distinction between "initial meanings" (significati di partenza) and "additional meanings" (significati aggiuntivi).

Whatever we utter is conditioned not only by the context of our discourse, but also by our conscious and unconscious assumptions as well as by our goals. During any process of interpretation, the interpreter bears in mind all those implicit assumptions which make understanding possible, and accepts them in so far as he/she accepts communication. Other meanings are then added to this initial situation; they are called "additional meanings". The two phases, the comprehension of the implicit aspects of communication and the addition of other meanings, are possible simply because an "initial meaning" exists. Such a meaning has a focal point, indispensable for the acquisition of meaning of the utterance and yet immediate, explicit and conscious.

At this point in his theory, Rossi-Landi is referring to the initial meaning as something that is immediately "conscious" and distinct from the additional meaning that, on the contrary, is not at all conscious even though it can become so later. In any case, the process here involved is one characterized by a succession of diverse degrees of consciousness. Even given its initial meaning, the utterance is "a vase to be filled, a paradigm to be applied, a schematic situation to be perfected via the ulterior meanings which must and can be attributed to it in all or specific circumstances" (1961: 203).

Hence, even in those cases in which utterances seem very simple, they actually contain a perfusion of information, which is complex and stratified, and refers constantly to something else. An apparently simple utterance such as "Tonino sta meglio" or the words of the song "Whatever Lola Wants, Lola Gets", can undergo a thorough interpretation only if the interpreter is "an educated contemporary who is a descendant of hundreds of thousands years of conscious evolution of the species, roughly five thousand years of [...] "history", which reflects Vico's and Hegel's historicism, existentialism and the Nouvelle Vague, the logical analyses of Plato, Hume and Wittgenstein, and so on" (1961: 187). Even those of us who are not aware of the totality of this heritage manage to react adequately to such utterance. In normal interpretation we never perform all the possible connections; the interpreter only aims to understand an individual utterance within a specific communicative situation.

Within this particular perspective, it does not make much sense to ask ourselves in what order meanings come to mind. "Once the materials have been blurted out in whatever order they have come to our minds, we order them in a different way, we structure them. [...] We are tempted to say that we order them in space and not in time"(1961: 197). In other words, Rossi- 


\section{Ocula ${ }^{16}$}

Semiotics of Economic Discourse | Semiotica del discorso economico

Cinzia Bianchi | Ferruccio Rossi-Landi: language, society and semiotics

Landi continues, the first person plural pronoun makes one think of the transcendental "I" and not of the various empirical "I's".

In this fashion, the a priori dimension both of the elements, and of the analysis that has been undertaken, is once again confirmed. One ought to bear in mind, though, that nowadays the a priori "is expanded and confused, fine and intricate, so much so that no philosophical system, founded on whatever doctrinal extrapolation, will ever be able to express, I am not saying thoroughly, but even only sufficiently, representational adequacy" (1961: 198).

\section{A priori in language and "mental work"}

In short, in Significato, comunicazione e parlare comune Rossi-Landi was looking for the pre-linguistic operations that stand at the very foundation of human thought. Later on ${ }^{10}$, he would admit that this research was "an idealistic, or rather Gentilian, hang-over, filtered ten years earlier with Silvio Ceccato's 'operative technique' and never fully removed"(1983:26). Rossi-Landi's position manifested itself in his constant references to "mental work". Such work assumed, then, "a certain mysterious quality in that it was supposed to be susceptible to study and to solution in separable, but interconnected units - and one could still suspect that this work unfolded by itself, in a realm of its own, independent of its linguistic or behavioral guise"(1983: 26). By stating this, Rossi-Landi had forgotten the teachings of Marx and Engels, that is, the idea that "from the beginning the 'spirit' is afflicted with the curse of being 'burdened' with matter, which here makes its appearance in the form of agitated layer of air, of sounds, in short, of language"(Marx-Engels 1845-46: 339). The only a priori which he later considered possible is weaker than the one deriving from the pages of Significato, comunicazione e parlare comune. In language (langage), and perhaps even in thought, there are more elements of "matter", such as ethnicity and historicity, than those considered by Rossi-Landi.

Often, however, the use of "mental" instead of "social" was not a conceptual residue but a terminological one. Rossi-Landi refused the idea that there is a unitary mental flux that can be articulated into operations. It is thus useful to create a theoretical model that, while not aimed at describing real processes, would allow us to study them in a more precise and conscious manner. We can still use the term "thought", but as a large family of concepts, referring to social and personal activities that are part of a human being's life. This family is related to other families that deal with verbal and non-verbal sign systems and with social institutions of every type. "This is what man's life is made up of, and this originates his thought" (1961: 27). Rossi-Landi was to admit the limitations of his previous speculation on thought when, twenty years later, he wrote in the second edition of Significato, comunicazione e parlare comune:

${ }^{10}$ See Rossi-Landi 1968b (1983, pp.24-27), 1978b (1990, pp. 71-75), 1979d. 


\section{Ocula ${ }^{16}$}

Semiotics of Economic Discourse | Semiotica del discorso economico

Cinzia Bianchi | Ferruccio Rossi-Landi: language, society and semiotics

thought is a syllogism and a sonnet, but also a dance [...]; there is thought in a verbal utterance, but there is thought in a well cooked steak. And if there are things that logic deals with, there are, also, many "logics" that things "deal with"(1961: 27).

In addition to this reconsideration by Ross-Landi of the work he had published in 1961, we consider it interesting to note Umberto Eco's analysis of the same book, that appeared in an essay that Eco wrote in 1987. When analyzing the concept of the a priori in language in Significato, comunicazione e parlare comune, Eco considers a specific example. Attempting to clarify some differences between "thought", "language" (langage) and "language" (langue), Rossi-Landi states that deaf-mutes, although unable to express themselves through verbal communication, possess a partial language "that functions as an intermediary between a spoken (or written) language and the process of thinking without speaking" (Eco 1987: 158). Therefore, if they express themselves through gestures, it follows that they possess "speech", an organization of concrete linguistic signs. Rossi-Landi then continues by stating: "a Polish deaf-mute remains silent in Polish and an Italian deaf-mute remains silent in Italian" (RossiLandi 1961: 158). Eco,while agreeing with the idea that a Polish deaf-mute assimilates a substantial amount of Polish culture through non-auditory channels and is, therefore, naturally inclined to think in Polish, argues that "if the thinking process reveals certain constants that precede not only the historical institution of languages but also the articulation and articulability of language, at this point, one can deny the universality of thought or admit that this intermediary faculty which is language and which the deaf-mute possesses and which is structured always a priori in respect to language, contains within it a relevant part of historicity and ethnicity (in our case of 'Polishness')"(Eco 1987: 17 my trans.). In these pages, Eco concludes, RossiLandi does not offer solutions on the question of the a priori, because "he wants the a priori before language and he is able to find it only in linguistic operations"(Eco 1987: 19 my trans.).

In my opinion, this also determines the problematic nature of RossiLandi's book, and leads to its inconclusiveness: the issues raised would be long debated among linguists and philosophers, even after the author had turned his attention to other theoretical horizons.

\section{Marxist semiotics}

After Significato, comunicazione e parlare comune, Rossi-Landi published nothing for four years. He dedicated this time to the study of the "classics" of philosophy, and particularly Marx and Hegel.

The Marxist turn of his semiotics looms from the first works published after this period of silence. The first essay written in 1965 is entitled: "Il linguaggio come lavoro e come mercato". This is also the title of the first of three collections published by Bompiani. This book (1968; English trans.: 


\section{Ocula ${ }^{16}$}

Semiotics of Economic Discourse | Semiotica del discorso economico

Cinzia Bianchi | Ferruccio Rossi-Landi: language, society and semiotics

Language as Work and Trade, 1983), collects the essays written from 1965 to 1967, while Semiotica e ideologia [Semiotics and Ideology], published in 1972, collects those written in 1966-1970, and Metodica filosofica e scienza dei segni [Philosophical Methodics and the Science of Signs], published in 1985, collects those written from 1971 to 1979.

These collections have a certain homogeneity and, as the author states, form:

a sort of unitary work with an interdisciplinary tendency, concerning various aspects of human sign systems which are interpreted on the background of historical-social reality; human sign systems that are part of reality and to which they contribute. A work which investigates how human sign systems, verbal and non-verbal, are produced and used, not only, but also how the human sign systems use us, and make us slaves, if not victims, because they are bearer of the ideologies which are imposed upon us, and of which we can try to free ourselves by innovating the sign systems themselves (1968b: 8 my trans.).

In 1974 he published Linguistics and Economics, written in English, and in 1978 a handbook: Ideologia (English trans. Marxism and Ideology, 1990), where he discusses the problematic relation between ideology and language. The English reader could also consult Ideologies of Linguistic Relativity (1973), a translation of one of his essays contained in Semiotica e ideologia.

\section{A Marxist reading of Wittgenstein}

The conceptual analysis of this phase of Rossi-Landi's work requires, as a point of departure, an understanding of his Marxist reading of Wittgenstein's ideas as they are presented in Philosophical Investigations. I believe that this interpretation is a good example of the methodology followed by RossiLandi during the transition from his first to his second theoretical phase. In fact, if one analyses the overall development of his work one discovers that there is a continuous increase in theoretical considerations; he passes from specific considerations in the linguistic field to studies on linguistic production and social reproduction. In this passage, the linguistic research previously accomplished is never rejected; authors and philosophical currents are re-interpreted from another point of view and included in the new horizon of research. In fact, Rossi-Landi's notes on Wittgenstein's research emphasize the incompleteness of his approach to language and underline three limits. ${ }^{11}$

The first one regards the "public" character of language; "public" linguistic games are not seen as a social being. He studied what happens when some "already formed" individuals begin talking to one another. Even when he described how we learn to talk as children, "the children he shows

${ }^{11}$ See "Toward a Marxian Use of Wittgenstein" in Rossi-Landi 1983, pp.1-64. See also Rossi-Landi 1979e, 1981a. For a discussion of this aspect of Rossi-Landi's theory see Bianchi 1994. 


\section{Ocula ${ }^{16}$}

Semiotics of Economic Discourse | Semiotica del discorso economico

Cinzia Bianchi | Ferruccio Rossi-Landi: language, society and semiotics

us are the offspring of adults who are already completely formed as individuals and who transmit to them linguistic techniques already in their possession". "In short, the idea Wittgenstein never seems to have grasped, or at least not as fundamental, is that individuals have socially formed themselves as individuals precisely because, among other things, they have begun to talk to one another"(1983: 30). The second limit concerns the notion of linguistic use. This is something that exists because it has already been produced. Therefore, one must ask how a word initially originated. Wittgenstein also "lacks the notion of labor-value, that is, of the value of a given linguistic object, in this case a linguistic object, as the product of a given linguistic piece of work"(1983: 31). Wittgenstein, like other philosophers from Oxford, only analyzed how we use the artifacts; he moved only from the linguistic object "forward" and never from the object "backwards" (see also Rossi-Landi 1985: 19 ff.). He considered the instruments for communication as "given to us" and therefore "natural"; they are as "a sort of wealth we find freely available"(1983: 31). The third point concerns Wittgenstein's insistence on philosophy as sickness and on defects of language. He proposed a sort of "logotherapy" to overcome the philosophical failures and the personal perplexities, due to the fact that language is "idling out of gear" and "going on holiday". This is an essential step towards the determination of what we may call linguistic alienation according to Rossi-Landi. However, he never asked himself why all this occurs or "what is the historical-social origin of these cramps and perplexities" (1983: 31). He did not "work back from the phenomena examined and denounced to their causes" - i.e. take into account the causes of the phenomena he examined - and he completely ignored the general doctrine of alienation; "he lacks a theory of society and history on which to base his research". Consequently, Wittgenstein's philosophy remained "a philosophy in part divorced from reality" (1983: 32).

In short, Wittgenstein's theory, as Rossi-Landi clearly stated, is limited to explaining a "public that falls short of the social", of "use that is not reconnected to work" and of "the separatism that keeps language detached from history" (1983: 33). One could accept his philosophy for what it offers and at the same time reject it for what it omits, Rossi-Landi commented. However, "this could also mean that one must accept it in its entirely, on the condition that one inserts his teachings in a broader framework; a framework to which his teachings undoubtedly make reference and yet of which there are merely a few traces of them in it". ${ }^{12}$

The Wittgensteinian doctrine of philosophy as activity can be accepted and amplified by the philosophy of praxis; "this activity will then be no longer or not only individual, but directly social"(1983: 33).

${ }^{12}$ See Rossi-Landi 1968b; 3rd Italian edition 1983: 194. This quotation was not translated in English edition of 1983. Therefore, the translation is mine. 


\section{Ocula ${ }^{16}$}

Semiotics of Economic Discourse | Semiotica del discorso economico

Cinzia Bianchi | Ferruccio Rossi-Landi: language, society and semiotics

The perplexities and mental cramps that Wittgenstein attacked continue, in fact, to emerge all over the planet and certainly not only in the heads of certain colleagues. They are a social fact of immense importance, not an individual distortion; they are rooted in history, in our institutions, in concrete interests, and not only in unspecified "temptations" or "inclinations" of individual speakers (1983: 33).

Even if Wittgensten's position is that of a "non-mechanistic materialist" which defines a human being as an actor in meaning and communication processes, it is a prevalently empirical and biological one. Its positive aspect concerns individuals already united by a social community. However, this is not sufficient for Rossi-Landi as his research shows.

Rossi-Landi maintained that reading Marx and Wittgenstein together made it possible to gain a new perspective. The former "gives the indispensable theoretical framework", while the latter provides "particular elaborations with regard to language" (1983: 34).

We should not underestimate this methodological approach, in fact, it was the only approach Rossi-Landi could have adopted to enable him to create "Marxist semiotics". If he had ignored the specific contribution of language scholars, he would never have proceeded beyond Marxist theory and this would not have led onto semiotics. If, on the other hand, he had ignored Marx's contribution, his research would have been limited to semiotics, while ignoring the production and consumption of messages, i.e. objects that characterize our society.

\section{The theory of homology}

The first theoretical step towards an analysis of the interpretation of human sign systems, in the context of historical-social reality, was RossiLandi's "theory of homology". We can discuss the homology of production since the complex human needs for expression and communication, which are no less important than the material ones, involve both material work and linguistic work. The products of these two kinds of work are different, but the process which constitutes linguistic and material objects is identical. In this way, linguistic work and non-linguistic work, "as species normally held arbitrarily separate, are reunited in the genus to which they both by equal right belong"(1983: 36) that is to the category of man himself, the historical result of his own work. A human being is "a working and speaking animal, who sets himself apart from all the others in that he produces tools and words [...] and with this production, which constitutes 'the social', historically forms himself"(1983: 36).

Rossi-Landi hypothesized a homology that was at the same time logicostructural and historical-genetic; consequently one ought to consider the anthropogenic character which gives origin to both material and linguistic artifacts. This may be employed to show that the two orders of production follow parallel modalities and levels of complexity for which unitary explanations may be given. Thus, we can note that human beings have never produced linguistic artifacts without producing material artifacts at the same 


\section{Ocula ${ }^{16}$}

Semiotics of Economic Discourse | Semiotica del discorso economico

Cinzia Bianchi | Ferruccio Rossi-Landi: language, society and semiotics

time, and vice versa; a civilization that was "only material" or "only linguistic" has never existed. Although there are cases where only material artifacts have survived as traces of extinct civilizations, this fact does not relate to their production. Furthermore, the production of these two types of artifacts is at the origin of homination. Indeed, the fundamental process of the origin of man involved the dialectic integration and overlapping of both biological and social-historical evolution.

The most radical characterization of human beings is that which emphasizes their ability to produce material (faber) and linguistic (loquens) artifacts. The infant, who is at the same time infans and inficiens, enters the world of linguistic artifacts "through the same process that brings him into the world of material artifacts; he accepts, or better submits to, the systems of products of both orders". "He could not learn to talk without learning to distinguish and manipulate objects, and he would not learn to distinguish and manipulate objects without learning to talk" (1983: 126). This is an ontogenetic reproduction of phylogenetic factors: "the child reproduces the entrance into the world of the species"(1983: 126).

Moreover, one must bear in mind that human beings do not communicate only through words, but use the whole social organization. Therefore, as Rossi-Landi stated, we must elaborate a theory for understanding the two fundamental modes of human behavior: production and circulation of goods (as commodities) and production and circulation of sentences (as messages).

The various types of human communication are constituently united and there is no natural division among them. Besides languages as systems of words that we use for passing on verbal messages, there are also non-verbal "languages", such as habits, rituals, customs, cookery and highway codes. These are systems of signs that stand as objects of study for semiotics, just like linguistic ones. Therefore, if language is composed of artifacts as human products, the other material products are non-verbal codes. In short, we have a division inside the genus sign: signs are divided between verbal signs and non-verbal signs on the basis of the existence of verbal communications and non-verbal communications.

Beyond the obvious differences between communication through verbal sign systems and non-verbal ones, Rossi-Landi often emphasized that "the study of any one of these sign systems turns out to be useful in the study of any other"(1983: 69). This is interesting, not only because we find immediate homogeneities in several structures or because the study of one of these offers some information for understanding others, but "above all because in studying one system or the other, we are basically studying the same thing"(1983: 69).

For this reason, in principle we can always hold as possible and valid both the operation of applying specifically linguistic considerations developed through study of the verbal, to non-verbal communication systems and the opposite operation which consists in utilizing considerations brought out through the study of this or that nonverbal sign-communications system in the study of verbal language (1983: 69). 


\section{Ocula ${ }^{16}$}

Semiotics of Economic Discourse | Semiotica del discorso economico

Cinzia Bianchi | Ferruccio Rossi-Landi: language, society and semiotics

Instruments elaborated in the study of verbal communication could be applied to various types of non-verbal communication, and vice-versa. This reciprocity of interpretation is an operation of the "application of the verbal to the non-verbal" on one hand, and on the other of the "application of nonverbal to the verbal".

The work of Lévi-Strauss ${ }^{13}$ is the most famous example of the first type of application. He studied marriage rules and kinship systems, having applied the glottological structures to anthropology. Marriage and kinship were a type of language and a group of operations destined to ensure a certain type of communication among individuals of the same community (Rossi-Landi 1983: 70 ff.).

Rossi-Landi chose to adopt the opposite approach, that of studying verbal language through methods employed in the study of non-verbal language. This method led to the formulation of a "homological schema"14. Economic communication offers us a "particularly intriguing and fruitful" schema for this. Rossi-Landi stated that by eliminating production and consumption as technological and physiological processes in his economic theory, Marx had investigated the manner in which a product (non-sign) becomes a commodity (sign) after material production and how it once again becomes a product, before material consumption. If we use semiotic language, we can say that Marx studied "the way in which the product is coded as a commodity and the commodity then de-coded as a product"(1983: 74). By learning from his work and looking "through the bodily density of the economic market, and beyond its non-sign aspects"(1983: 80), we have recognized that the economic system is truely a language. Therefore, since we are comparing two aspects of the same process, it is not only possible but also fruitful to use Marx's means to conduct a certain type of investigation dealing with verbal language. ${ }^{15}$

13 See, for instance, Lévi-Strauss 1958.

14 Rossi-Landi explains the similarities between two kinds of artifacts during the several steps of "working", through the homological schema. Some passages between levels are more important than others: the passage from intact nature to matteremes and phonemes; from these to objectemes and monemes; from objectemes and monemes to utensils and sentences; from these to machines and syllogisms; from these to automated machines, that is to non-verbal and verbal program-bearingcodes. "For each of the levels in which a qualitative leap is realized, the artefacts, whose production is made possible by that leap and whose structure is characterized by it, so to say pour out of the productive process and stay there waiting"(1975b: 108). That is the parking lots of artifacts. Workers can learn to use "parked" artifacts, even if they do not know their whole productive process. In fact, we generally use the artifacts without this knowledge. The consumer goes to the parking lot, gets his car, and goes on about his new work; the artifacts are assumed "in their new immediacy", "in themselves and by themselves". See Rossi-Landi 1968b, chap. V, pp. 107-117 (1983, chap.VI, pp.118-152); 1972, chap. 6, pp.57-63 and chap. 13, pp.249-258; 1975b, chap. 3 , pp.70-120; 1985, chap. 3, pp.47-84.

15 These arguments allowed Rossi-Landi to use the conceptual framework of Marxism and he spoke of "linguistic capital", "linguistic alienation", "private property in language ", and so on. Languages are composed of linguistic material, instruments and money, which make up the constant linguistic capital of all further linguistic 


\section{Ocula ${ }^{16}$}

Semiotics of Economic Discourse | Semiotica del discorso economico

Cinzia Bianchi | Ferruccio Rossi-Landi: language, society and semiotics

\section{Metaphoric aspects of the theory}

In considering the theory of homology some linguists, as well as certain Marxists, ${ }^{16}$ have detected a metaphoric excess and the dangers implicit in the transposition of diverse methodologies from a material to a linguistic field. As stated by Rossi-Landi, scholars have often believed that theory should be a comparison of fields subject to diverse historical determinations, yet conserving the same level of abstraction. Application of Marxian principles to the field of language and communication would then be charged with an explicative and applicative urgency, and thus go beyond the simple observation of what happens in communication. Such an application would thus imply an excessive and merely metaphoric homological relevation.

The difficulty in understanding Rossi-Landi's theory is also determined by the use of terms which are then characterized ideologically. As Rossi-Landi maintained, it would have been possible to avoid the use of certain terminologies that had been undermined by Marx's reflections on capitalism; for instance, opting for "patrimony" or "richness" instead of "linguistic capital".

No one will want in fact to deny that language is a patrimony shared in a more or less large measure by whoever is born in a determinate linguistic community, and transmitted from generation to generation; and (one hopes) many will admit that the speakers are not beautiful and complete individuals who undertake all of a sudden to employ the language of their community, a language which was previously extraneous to their formation (1980: 358).

This terminological choice obviously indicates the conceptual background of the author; a fact that is not irrelevant is that the terms "capital" and "patrimony" do not belong to the same semantic field. To speak of "patrimony" might appear to be less metaphoric, pertaining more to our conception of language and its terminology. However, this concerns the dialectic between literal and metaphorical meanings and reveals the difficulty in formulating a convincing theory of literality.

work, that is of all expressions and communication. Constant linguistic capital "is a dead thing unless it is accompanied by a variable capital consisting of the linguistic labor power expended by the men who speak and understand a given language, who express themselves and communicate in it"(1983: 47). It is difficult to interpret the languages without the variable capital. When a linguist sets out to interpret a dead language, "he is like a person who goes into an abandoned factory and starts up long silent machines after having discovered how they work"(1983: 47). Constant and variable capital together make up total linguistic capital, through communication occurs. Communication is the production and circulation of messages within a linguistic community, which appears as "a sort of huge market in which words, expressions and messages circulate as commodities"(1983: 49). See Rossi-Landi 1968b (1983 pp. 109-111 and 153-170); 1974a (1980); 1975b, pp.146-158; 1985, chap. 6, pp.115-136.

${ }^{16}$ See, for instance, "Preface to the American Edition" in Rossi-Landi 1983: ix-xv. 


\section{Ocula ${ }^{16}$}

Semiotics of Economic Discourse | Semiotica del discorso economico

Cinzia Bianchi | Ferruccio Rossi-Landi: language, society and semiotics

It is not possible to point out what is "per se" literal without having a reductionist conception of language, Rossi-Landi claimed. One could study the transition from the literal to the metaphorical in the linguistic process or distinguish between proper and simple meanings and complex, mediate, more contextualized ones. However, this does not allow us to distinguish between the literal and metaphorical meanings of words in a definite manner; and things certainly become more complex if, instead of dealing with words, we deal with sentences, and so on.

Both the definition of literal as referring to what is physically observable in an intersubjective way, and the idea of language as a labelling, fail to account for the complexity of linguistic results. The former does not consider that different people, cultures and ages may experience the same physical phenomena in different ways. The latter, believing that the linguistic nucleus is reached in a definite way, is not sufficient to study the literal nucleus and "we would have to get down to the level of the 'protocols' of language so beloved by neopositivists"; "only such protocols could really be literal, because they are free of any semantic ambiguity and thus are entirely intersubjective"(1990: 209). For this reason, literalness is a philosophical myth if it is not a product "restricted and specific to the scientific methodology of a particular field of studies" (1990: 209).

The metaphorical also has its risks and if it surpasses certain limits, it "becomes the uncontrollable vehicle of the vitalistic and irrational"(1990: 210). Excess of literality and excess of metaphoricity are both inadequate means for examining a theoretic object critically and for interpreting it in a non-conventional way. In any case, Rossi-Landi adds, "it is better to have a controlled measure of metaphoricity with its richness than an excess of literality with its insuperable fundamental restrictions and with the metaphysics that stand behind it" (1980: 351; see also 1990: 211).

Therefore, if one assumes that he was thinking solely of a transposition of notions from an economic field to a linguistic one, one can conclude that he was adopting a metaphoric process. However, Rossi-Landi's intention is to elaborate a theory that explains the two fundamental human behaviors, without overlooking the fact that such behaviors arise from the same historical and social process of homination.

The indispensable connection between every sign system leads us to a new consideration of the relations among them, and particularly between the verbal sign system and the others. If language, Rossi-Landi said, is only one of numerous sign systems present in a society and is not independent of the others, then one must be cautious about its priority in relation to the others. It is not even true that the other sign systems depend on it; on the contrary, the opposite would appear more likely. In fact, not only non-verbal sign systems have preceded genetically and flounced language, but language is also "upheld" on the other sign systems. We can only say that language is the richest, because it is able to describe the others approximatively, thanks to its great use in communicative practice. In any case, we ought to be cautious when attributing more importance to it than it actually has in the life of a community. 


\section{Ocula ${ }^{16}$}

Semiotics of Economic Discourse | Semiotica del discorso economico

Cinzia Bianchi | Ferruccio Rossi-Landi: language, society and semiotics

From this consideration of verbal language comes the necessity to use the instruments of the linguistic field correctly in order to analyze the nonlinguistic field. What is very important is that Rossi-Landi's approach allows us to study verbal language with instruments from material production. In such a manner, one can avoid the "logo-centric approach" of semiotic analysis that originates from the use of a unilateral application of linguistic categories to the non-linguistic field. Consequently, the linguistic instruments are not considered pre-eminent when analyzing all the phenomena present in the world.

Rossi-Landi's attempt is neither a banal transposition of instruments from one discipline to another, nor a theoretical expedient that places linguistic studies in a Marxist paradigm. Therefore, the existence of a methodological problem, which has been partially emphasized through reflection on literality and metaphoricity, is evident.

Are we allowed to use instruments pertaining to a certain discipline to study phenomena that were analyzed traditionally with other methods? Could a discipline lose its identity if theoretical thresholds are crossed?

The "polemical graft" between Marxism and semiotics, made by RossiLandi, is a good example of how intellectual research should be conducted. The problems of research that is at the borders of a discipline, yet is able to draw the strength to discover new links and raise new issues from this very marginality, are evident. Such questions must be considered more deeply, especially by those who work in a relatively new discipline like semiotics which is still susceptible to strong external influences - influences which have given life-blood to this discipline.

\section{Linguistic peculiarities}

Instead of considering his theory as metaphoric, one could raise some objections about Rossi-Landi's tendency to trace every homological element between the two productions, without pointing out the diversities, that are merely hinted at in several texts.

$\mathrm{He}$ continually stated that there are two fundamental dimensions of language that are usually disregarded, which we can better understand as work and trade. These are only two of several dimensions present in language and we must add them to the others. Rossi-Landi does not deny that there are many other dimensions in language, like the ludic one, even though he does not aim to analyze them all to arrive at an omnicomprehensive theory of language.

By pointing out parallelisms and homologies, his approach is not only exhaustive in relation to all linguistic dimensions, but, at the same time, it does not help us to find the peculiarities of both productions, that derive, like homologies, from an historical process.

The similarities, Rossi-Landi stated, should not force us to forget that there are differences. Nobody intends to deny them; but these should be brought out and organized only after the similarities have been examined. 


\section{Ocula ${ }^{16}$}

Semiotics of Economic Discourse | Semiotica del discorso economico

Cinzia Bianchi | Ferruccio Rossi-Landi: language, society and semiotics

However, the organization of the peculiarities, as fundamental process as that of the identification of homologies, is never actually carried out: the differences are always indicated briefly and are accepted as "obvious". According to Rossi-Landi's statements on other occasions, ${ }^{17}$ the analysis of what may appear at first glance obvious, could lead to important theoretical changes. Often the obvious is disregarded in favour of what seems less obvious. In fact, discussion of the obvious has always been more difficult than not speaking about it, simply because it appears familiar. Therefore, it is fruitful to add the dimensions that derive from considerations of language as work and trade to those usually recognized in language, but it would be equally interesting to reconsider those already existing after establishing these new dimensions.

Borrowing Rossi-Landi's metaphor to illustrate that the two productions are the same "at least in the sense that the two main branches of one and the same tree are the same thing"(1983: 65), one can say that it is appropriate, referring to the tree as a whole, but inappropriate if one refers to the single branches. Two separate branches of any tree are not the "same" branch otherwise it would be incorrect to talk of "two branches". Since every branch has undergone a specific development and has a relationship of continuity with the others, it acquires peculiarities which make it "this" branch and not another. An analysis of this type should not be based on considerations of superficial differences because this cannot in any way replace the general analysis on philogenetic and ontogenetic homology; it could examine carefully peculiarities already existing. However, one must not consider the statements of other scholars, who have perhaps not considered the new homologic elements, to be exhaustive.

Although the importance of this theory must be recognized, one cannot arrive at an exhaustive theory of language only through Rossi-Landi's contribution; indeed, this was never his intent.

\section{Social reproduction}

In the 1970s, Rossi-Landi considered it necessary to study the whole of social reproduction, because it is the matrix of all possible categories. He often defines social reproduction as the process by which every society or community is formed, grows and continues to exist ${ }^{18}$. The fundamental moment of social reproduction is the production of goods: in fact, for individuals there are some "primary" needs, like eating, drinking and protecting oneself from inclimate weather. Even if human beings must join together in groups and set in motion complex superindividual procedures in order to satisfy these needs, one of these needs will be verbal communication.

\footnotetext{
${ }^{17}$ See, for instance, Rossi-Landi 1961: 55-57.

${ }^{18}$ See particularly Rossi-Landi 1975b, chap. 2 (pp. 31-69) and 3 (pp. 70-120); 1977; 1978a; 1978b (1990); 1985, chap. 2 (pp. 27-45), 8 (pp.175-185) and 11 (pp .238242); 1986.
} 


\section{Ocula ${ }^{16}$}

Semiotics of Economic Discourse | Semiotica del discorso economico

Cinzia Bianchi | Ferruccio Rossi-Landi: language, society and semiotics

When we say "there is nothing that does not belong to social reproduction", we are not claiming that material phenomena like stones or trees do not exist "on their own account", "independently of human action", or that there was no geological and biological evolution before the social one or that human being's bodies are not subject to biological laws. We want to assert that every object, "whatever type or order of existence it has, always has to be identified, appropriated, and made use of within the sphere of social reproduction", as Rossi-Landi stated. Every discourse we make, "is a form, aspect, or factor of social practice" (1990: 54). The same conception of nature as external to the human being is "a mode of seeing and interpreting reality, [...] an object which they have constructed by means of their thought"(1990: 55). Therefore, it is an expression of social reproduction, ideologically and historically influenced by social reproduction itself. Every theory of nature, of humanity, of society and of history is internal to social reproduction. In this way, this is the fundamental category, the principle of all things and the structure that is always present. In other words, it is the sum of natural and historical factors, constructed by human beings during the production and reproduction of themselves.

Marxist tradition has handed down to us two models of social reproduction: 1) the triadic separation of production, exchange and consumption and 2) the opposition between structure and super-structure.

The first model clarifies that the three principal elements in every case of social reproduction are production, exchange and consumption. They are separate sphere, but are closely and inextricably connected; one cannot exist without the others. ${ }^{19}$ Production, exchange and consumption are not solely concerned with material goods, but also with the so-called cultural or spiritual goods, "and every other kind of social institution, value systems, and the distribution and organization of individuals within the social system. Everything is continually being produced, exchanged and consumed"(1990: 59). In Linguistics and Economics (p. 65), Rossi-Landi proposed a schema regarding social reproduction.

Social reproduction always comprehends, in a constitutive way, three indissolubly correlated moments:

\begin{tabular}{|c|c|c|}
\hline \multirow{3}{*}{$\begin{array}{l}\text { 2. EXCHANGE, which is } \\
\text { always, at the same time } \\
\text { and constitutively, }\end{array}$} & \multicolumn{2}{|c|}{$\begin{array}{l}\text { A - external material EXCHANGE, that is, the process } \\
\text { of exchanging not signs but bodies; }\end{array}$} \\
\hline & \multirow[t]{2}{*}{$\begin{array}{l}\text { B - sign EXCHANGE, that is } \\
\text { communication, including as } \\
\text { such and within it: }\end{array}$} & $\begin{array}{l}\text { i - sign production, } \\
\text { ii - sign EXCHANGE in the strict } \\
\text { sense, and }\end{array}$ \\
\hline & & iii - sign consumption. \\
\hline
\end{tabular}

3. External material c o n s u m p t i o n, which, even when it uses signs, consumes not signs but bodies.

19 See Marx, 1857-58, "Introduction". 


\section{Ocula ${ }^{16}$}

Semiotics of Economic Discourse | Semiotica del discorso economico

Cinzia Bianchi | Ferruccio Rossi-Landi: language, society and semiotics

Within the fundamental triad, production - exchange - consumption, we find the triad of sign production in the central stage of exchange. Exchange has both an "external material" characteristic and a sign one. In fact, verbal and non-verbal messages, like anything else, must be produced and consumed and not simply exchanged.

The second model of social reproduction is the opposition between means of production - the base in any instance of reproduction - and the so-called superstructure. "This includes everything not directly concerned with the mode of production but more or less detached from it and so endowed with relative autonomy, following, though never exclusively, its own laws of development". The superstructure, characterized by an ideological factor, "consists of all institutions, except the directly economic-productive or the solely existential, as well as artistic, literary, scientific, religious, and political activities" (1990: 60).

\section{The role of sign systems}

In both models of social reproduction, sign systems play a very important role. They are already present in every mode of production and in every ideology, but they do not exhaust themselves within such categories. If exchange is production and consumption, and in turn production is exchange and consumption, and so on, by the same token modes of production and ideologies are sign systems; once again there is dialectic unity. Sign systems are neither structure nor superstructure. However, this does not imply that they are hypo-structural or infra-structural.

They are an integral part of social reproduction; they operate within it at every level and are open to its influence. At the same time, sign systems "have a relative independence of their own, which permits development in accordance with organizational laws proper to them alone" (1981b: 29).

For all these reasons, Rossi-Landi thought that the introduction of sign systems as intermediary between modes of production and ideologies, resolves two kinds of problems. The first regards the identification of language -as one of sign systems - with one of two dimensions of social reproduction. The second resides in the difficulties always encountered in analyzing relations between base and superstructure. Hitherto, Rossi-Landi argued, we had attempted to approach a triadic situation binarily: it is necessary to add sign systems, which have emerged from the analysis of neocapitalism, to the modes of production and to the ideological elaborations of superstructure. The entirety of sign systems, and not only verbal signs, is the intermediary in either direction between the other two; from base to superstructure and vice versa, with the retraction of the superstructural elements to modes of productions. ${ }^{20}$

${ }^{20}$ Rossi-Landi's position, although similar for certain aspects to the one taken by Bakhtin-Voloshinov (1929), differs from it as regards the relationship between verbal and non-verbal signs. Even if Bakhtin and Voloshinov state that verbal signs are not independent from the extra-verbal context, Rossi-Landi points out that the issue 


\section{Ocula ${ }^{16}$}

Semiotics of Economic Discourse | Semiotica del discorso economico

Cinzia Bianchi | Ferruccio Rossi-Landi: language, society and semiotics

The importance of sign systems as intermediaries between modes of production and ideological institutions arises for several reasons, among which one may include their enormous variety and complexity and their unconscious and superpersonal character. Frequently "we know no more than that we are operating some sign system or other without any knowledge of how it functions". Frequently, too, "we do not even know that we are operating a sign system" (1990: 68-69). On the contrary, we may say that the sign system uses us, and not vice versa. Our own consensus appears to us not only "spontaneous", but even "natural". In the same way, we also move "spontaneously" and "naturally" inside the commodities system. ${ }^{21}$

\section{The mediation of semiotics}

Given that semiotics studies sign systems, it could act as a mediator between modes of production and the dimension of ideology in social reproduction, providing an analytical contribution to both fields.

On this point, Teresa De Lauretis raises doubts reharding the fact that the role of mediator assigned by Rossi-Landi to semiotics in reality is not observed. Given the fact that both economy and ideologies must be treated as sign systems and must be considered homologous to language, "semiotics appears as a kind of universal key to the entire spectrum of phenomena, which are thus precisely homologized by semiotics"(De Lauretis 1978: 8). In this way, according to De Lauretis, Rossi-Landi expected to have a scientific knowledge of reality inherited from the Marxist tradition that dominated the Italian cultural scene during the seventies. To counter this opinion, we would like to refer to some of Rossi-Landi's observations on semiotics.

Semiotics, together with linguistics, is regarded primarily as one of numerous components that must be analyzed, if one wants to undertake a criticism of human science as is presented in Ideologie. ${ }^{22}$ Besides semiotics

concerning the position of language cannot be separated from the position taken by all the other sign systems. Therefore, one must speak of sign systems and not only of language, since language is only one of the numerous and complex sign systems needed by a society to reproduce itself. See 1978b (1990: 238-247).

${ }^{21}$ See Rossi-Landi 1990, part 3: "Ideology as Social Teleology" (pp.275-344) and 1983, chap. 4 (pp. 83-106). Marxism and Ideology is a book in which Gramsci's work is the most important reference. See Biancofiore - Ponzio 1987, in which the authors point out some Gramscian ideas that were useful to Rossi-Landi. Gramsci's concept of "automatism" corresponds to Rossi-Landi's conscious use of programmes (see 1990: 286 and passim); the function of sign systems in social reproduction corresponds to Gramsci's concept of "civil society"; the concept of "common sense" acquires for both authors a certain ambivalence; "common sense" could refer to the area in which there are stereotypes and that which is common place became crystalized, but it could also be considered a reference point which one must not stay too for while undertaking a philosophical analysis; we have the same definition of "dominant class" as the class in control of the production, circulation, and interpretation of the verbal and non-verbal messages, which are in one community. See also Gramsci 1966, 1971, 1975.

${ }^{22}$ It was founded and edited by Rossi-Landi at his own expence, from 1967 to 1972. This journal which supported ideologically the student's protest of 1968, attests 


\section{Ocula ${ }^{16}$}

Semiotics of Economic Discourse | Semiotica del discorso economico

Cinzia Bianchi | Ferruccio Rossi-Landi: language, society and semiotics

and linguistics one must consider for instance "dialectics which includes as its static moment formal logic, anthropology in its various subdivisions, psychology and psychiatry as a whole, politics and sociology (both of which are also understood as a whole), economy and theory of ideologies, the science of rules/norm (low, morality, custom, etc.), ethics as a science of preferential behaviors and of individual responsibility, esthetics as the study of the artistic message on of its concrete circulation; and at last, historiography as the process of interpreting and reconstructing the past (without the fear of arriving at the threshold of the present); a process which applies and verifies ideological models taken from the social project that followed and that is diacronically enclosed but at the same time dependent on other synchronic structures" (Rossi-Landi 1968f: 5 my trans.).

Furthermore, at the core of his semiotics, we find what Rossi-Landi defined as the "theory of sign residues". 23 Through this theory, he reaffirmed the existence of non-sign elements even in sign phenomena; every body could become a sign even if as a sign it maintains non-sign characteristics. These characteristics cannot be dealt with by semiotics unless we want to engage in a contemptible, though fashionable, "Semiotical Panlogism" that must fiercely opposed.

Therefore, we agree with De Lauretis when she states that Rossi-Landi expected to have a scientific knowledge of reality, even if we prefer to speak of a systematic comprehensive knowledge. However, while semiotics is a very important means for analyzing reality, we do not believe that it acquired a universal role for Rossi-Landi. Both economy and ideology, together with all the phenomena present in all general categories, are studied semiotically only in their sign component.

In his last contributions Rossi-Landi pointed out that both sign and nonsign elements must find a place within social reproduction, even though he dealt only with the former. Having clarified this point, one needs to acknowledge that semiotics, although it studies a very vast field and does not have a universal characteristic, acquires a very important and demystifying role.

In fact, if we reflect on the process from which our consensus arises, we can demystify the ideologies that sign systems (especially the verbal one) transmit and participate in the project of consciousness. Mass communications, linguistic and semiotic research were important for RossiLandi, simply because they develop the consciousness of social programming

to the authors political-militant commitment. In Ideologie, one perceives a theoretical- practical commitment directed both towards the analysis of contemporary ideologies and towards the revisiting of themes such as communist polycentrism, neocapitalist ideologies, the background of some political and cultural revolutions, such as that of the cuban and chinese revolutions. Rossi-Landi deems it necessary to redefine some of the concepts in political practice or in the human sciences; his goal is that of demystifying their foundations which he finds at times unknowingly bourgoise, so as to be able to undertake unwitting by later a political struggle.

23 See Rossi-Landi 1979b, 1979c, 1985 (chap. 7, pp.137-166). 


\section{Oculla ${ }^{16}$}

Semiotics of Economic Discourse | Semiotica del discorso economico

Cinzia Bianchi | Ferruccio Rossi-Landi: language, society and semiotics

and teleology in every individual to which, willingly or unwillingly, we must submit. Once conscious of the rules that govern human beings' production, specific strategies must be employed to change the existing rules. In short, Rossi-Landi affirmed, if we are capable of making individuals understand that different ways of interpreting the world exist and that other criteria of choice exist, it is possible to make changes to the material life of human beings.

The great trust in semiotics and other linguistic studies that Rossi-Landi's work displays is probably a historically dated aspect linked to the Utopia of the seventies. In fact, although the idea of changing society starting from sign systems (aided by them or through their analysis) could be considered a good ethical motivation for many semioticians and scholars of mass communication, it is no longer feasible. Naturally, my intent is not to diminish the importance of sign systems and of the disciplines that study them, as so carefully outlined by Rossi-Landi; what we lack is the conviction that semiotics and intellectual output alone can enable us to condition social practice decisively.

Even the Rossi-Landian perspective of a global approach to the entire human existence through a omnicomprehensive model in which social production and reproduction, both semiotic and non-semiotic, verbal and nonverbal, take on a stable although dynamically defined place, can be considered as a historically dated attitude. Thirty years after his death, semiotic research has focused on other areas, although many of the problems posed to us by Rossi-Landi have not been resolved. The search for a convincing theory to explain the relationship between material production and linguistic production, especially in the era of neo and post-capitalism, is in my view entirely open. It is unlikely that the tools provided by Rossi-Landi will enable us to respond to the issues that this new socio-economic and cultural setting raises. However, it is equally true, as mentioned earlier, that subject areas often identify further fields of investigation not because they have resolved problems tackled earlier, but simply because the tools they possess are unable to provide plausible answers. I believe that this is one of the facts that clearly emerges from my reading of Ferruccio Rossi-Landi's Marxist semiotics. 


\section{Ocula ${ }^{16}$}

Semiotics of Economic Discourse | Semiotica del discorso economico

Cinzia Bianchi | Ferruccio Rossi-Landi: language, society and semiotics

\section{References}

Backtin, Mikhail; Voloshinov, Valentin N.

1929 Marksizm i filosofija jazyka, Leningrad: Priboj [Second ed. 1930; English trans. as Marxism and the Philosophy of Language, New York: Seminar Press, 1973].

Bernard, Jeff; Bonfantini, Massimo A.; Kelemen, Jánoš; Ponzio, Augusto

1994 (eds), Reading su Ferruccio Rossi-Landi: semiosi come pratica sociale, Napoli: Edizioni Scientifiche Italiane.

Biancofiore, Angela; Ponzio, Augusto

1987 "Il metodo omologico: Rossi-Landi e Gramsci", in Petrilli S. (ed.) 1987a, pp. $25-46$.

Bianchi, Cinzia

1994 "Rossi-Landi e la filosofia analitica del linguaggio", in Bernard, J.; Bonfantini, M.; Kelemen, J.; Ponzio, A. (ed.), 1994, pp.95-111.

1995 Su Ferruccio Rossi-Landi, Napoli: Edizioni Scientifiche Italiane.

2003 "Rossi-Landi e la semiotica del sociale: un confronto con le più recenti teorie socio-semiotiche", in S. Petrilli (ed.), 2003-2004, pp. 133-143.

Bridgman, Percy W.

1927 The Logic of Modern Physics, New York: The Macmillan Company.

Caputo, Cosimo

1994 "Semiotica generale e parlare comune in Hjelmslev e Rossi-Landi", in Bernard, J.; Bonfantini, M.; Kelemen, J.; Ponzio, A. (ed.), 1994, pp. 161-173.

1996 Materia signata. Sulle tracce di Hjelmslev, Humbolt e Rossi-Landi, Levante, Bari.

2005 "Ferruccio Rossi-Landi e la filosofia analitica", Segni e comprensione, XIX, 54, pp. 113-119.

Ceccato, Silvio

1951 Il linguaggio con la tabella di Ceccatieff, Paris: Hermann.

De Lauretis, Teresa

1978 "Semiotics, Theory and Social Practice. A Critical History of Italian Semiotics”, Cine-Tracts 2 (1), pp. 1-14.

Dingler, Hugo

1931 Geschichte der Naturphilosophie, Bonn: Deutscher Buchvertrieb Schmidt.

1936 Die Methode der Physik, München: Reinhardt.

Eco, Umberto

1987 "Whatever Lola Wants. Rilettura di una rilettura", in Petrilli (ed.) 1987a, pp. $13-23$.

Gramsci, Antonio

1966 Gli intellettuali e l'organizzazione della cultura, Turin: Einaudi.

1971 Quaderni dal carcere. Selections from the Prison Notebook of Antonio Gramsci, London: Lawrence and Wishart.

1975 Quaderni dal carcere, Turin: Einaudi [Critical edition by the Istituto Gramsci, edited by Valentino Guerratana. English translation as Prison Notebooks, 3 vols., New York: Columbia University Press, 1992-ff.].

Lévi-Strauss, Claude

1958 Anthropologie structurale, Paris: Librairie Plon [English trans. as Structural Anthropology, New York: Basic Books, 1963]. 


\section{Ocula ${ }^{16}$}

Semiotics of Economic Discourse | Semiotica del discorso economico

Cinzia Bianchi | Ferruccio Rossi-Landi: language, society and semiotics

Marx, Karl

1857-1858 Grundrisse der Kritik der politischen Ökonomie, Berlin: Dietz Verlag, 1953 [Some passages have been translated into English in K. Marx, Precapitalism economic formations, New York: International Publishers, 1965. Also vol. 28 of The Collected Works of Marx and Engels, London: Lawrence and Wishart, 1975-ff.].

1867 Das Kapital. Berlin: Dietz, 3 volls. [The publication of second book is of 1873 and the third is posthumous. English trans. as Capital: a critique of political economy, New York: International Publishers, 1967].

Marx, Karl; Engels, Friedrich

1845-1846 Die Deutsche Ideologie, Berlin: Dietz Verlag [English trans. as The German Ideology, New York: International Publishers, 1963].

Moore, George Edward

1922 Philosophical Studies [1903-1920], London: Routledge \& Kegan Paul.

1959 Philosophical Papers [1923-1955], London: Allen and Unwin.

Morris, Charles

1938 Foundations of the Theory of Signs (in International Encyclopedia of Unified Science I, 2), Chicago: University of Chicago Press.

1946 Signs, Language and Behavior, New York: Prentice-Hall.

1964 Signification and Significance. A Study of the Relations of Signs and Values, Cambridge Mass: M.I.T. Press.

1971 Writings on the General Theory of Signs, The Hague: Mouton.

Petrilli, Susan

1987a (ed.) Il Protagora. Per Ferruccio Rossi-Landi, 11/12.

1987 b "Il contributo di Rossi-Landi allo studio di Charles Morris", in Petrilli (ed.) 1987a, pp. 105-114.

1988 (ed.) Charles Morris, Segni e valori, Bari: Adriatica.

1992 "Introduction", Semiotica. Special Issue, The correspondence between Morris and Rossi-Landi, S. Petrilli (ed.), vol. 88, 1/2, pp. 1-36.

2003-2004 (ed.) Athanor. Semiotica, filosofia, arte, Letteratura, "Lavoro immateriale", XIV n. s., 7, Rome: Meltemi Editore [Atti of the International Conference intitled: "The Relevance of Rossi-Landi's Semiotics Today" (Bari, 14-16 novembre 2002)].

Ponzio, Augusto

1986 "On the signs of Rossi-Landi's work", Semiotica, 62, 3/4, pp. 207-221.

1988a Rossi-Landi e la filosofia del linguaggio, Bari: Adriatica.

1988b "L'eredità di Giovanni Vailati nel pensiero di Ferruccio Rossi-Landi”, M. Quaranta (ed.) Giovanni Vailati nella cultura del '9oo, Bologna: Forni, pp. 103-118.

2008 Linguaggio, lavoro e mercato globale. Rileggendo Rossi-Landi, MilanoUdine: Mimesis.

2012 Ferruccio Rossi-Landi e la filosofia del linguaggio, Lecce: Pensa MultiMedia.

Ryle, Gilbert

1949 The Concept of Mind, London: Hutchinson.

1953 “Ordinary Language”, Philosophy Review, LXII, 2, pp. 167-186.

Rossi-Landi, Ferruccio

1949 Storia filosofica della scienza, Italian trans. of Geschichte der Naturphilosophie by Hugo Dingler, with S. Ceccato. Milan: Longanesi.

1950 Critical notes, reviews and discussions in Methodos 1950 and 1951.

1951 "De la communication d'une langue au point de vue épistémologique et au point de vue opératif", Congrés international de Philosophie des Sciences, Paris, Sorbonne, 1949. Actes, I (Epistémologie), Paris: Hermann, pp. 177182. 


\section{Ocula ${ }^{16}$}

Semiotics of Economic Discourse | Semiotica del discorso economico

Cinzia Bianchi | Ferruccio Rossi-Landi: language, society and semiotics

1952 "Sugli scritti di Eugenio Colorni”, Rivista critica di storia della filosofia, VII (2), pp. 147-153.

1953a Charles Morris [1951-1952] (Storia universale della filosofia 21), RomeMilan: Bocca [reprinted in 1975d].

1953b "Towards an Analysis of Appraisive Signs in Aesthetics”, Methodos, V (18), pp. 103-120.

1953c “Socialità nella filosofia inglese contemporanea”, Comunità, VII (17), pp. 4345 .

1953d "La filosofia come analisi del linguaggio", XVI National Congress of Philosophy (Bologna, 1953), Atti, Rome: Bocca, 674-680.

1954 Lineamenti di una teoria dei segni. Introduction, translation and comment of Foundations of theory of signs by C. Morris, Turin: Paravia [2nd ed. 1963, $3^{\text {th }}$ ed. Lecce: Manni, 1999].

1955a Lo spirito come comportamento [1953]. Revisited Italian edition of The Concept of Mind by G. Ryle, Turin: Einaudi [2nd ed. 1982].

1955b "Del tipo di lavoro svolto da Gilbert Ryle", Introductory assay of 1955a, pp. XI-LIV.

1955c "Sulla mentalità della filosofia analitica” Rivista di filosofia, XLVI (1), pp. 48-63.

1955d "La filosofia analitica di Oxford", Rivista critica di storia della filosofia, X (1), pp. 69-84.

1955e "L'eredità di Moore e la filosofia delle quattro parole", Rivista di filosofia, XLVI (3), pp. 304-326.

1955f "La filosofia analitica”, Il Contemporaneo, II (50), pp. 10-11. [Six letters exchanged with L. Lombardo-Radice].

1956 "Di alcune modalità del filosofare", Rivista di filosofia, XLVII (3), pp. 267295.

1957a "Some modern Italian philosophers: 1 . The knife-grinders; 2. The pontiffs", The Listener, LVII (1450), pp. 59-61; (1451), pp. 97-98. [Conversation held on the third program of BBC (December 1956)].

1957b "Osservazioni sul nuovo corso della filosofia italiana", Rivista di filosofia, XLVIII (3), pp. 298-304.

1957c "Sul carattere linguistico del filosofare", Aut-Aut, 39, pp. 268-284.

1957d Introduction and notes of Il metodo della filosofia, Bari: Laterza [Eleven essays by G. Vailati, new ed. Bari: Graphis, 2000].

1957e "Una nuova lettura di Giovanni Vailati”, Cultura moderna, 30, pp. 17-19.

1958a "Universo del discorso e lingua ideale in filosofia" [1956]. In Il pensiero americano contemporaneo, 2 vols., F. Rossi-Landi (ed.), Milan: Edizioni di Comunità.

1958b "La filosofia della scienza in Italia" [1956] (with Vittorio Somenzi) in AA.VV. La filosofia contemporanea in Italia. Società e filosofia di oggi in Italia, Asti-Rome: Aretusa, pp. 407-432.

1958c "Materiale per lo studio di Vailati”, Rivista critica di storia della filosofia, XII (4), pp. 468-485 (1957); 13 (1), pp. 82-108.

1958d "Universi del discorso", Rivista di filosofia, XLIX (3), pp. 394-421.

1959 "Critica metafisica e filosofia analitica", Rivista di diritto civile, V (2), pp. 201-215.

1961 Significato, comunicazione e parlare comune, Padua: Marsilio [2nd ed. 1980, 3rd ed. 1998].

1965 "Il linguaggio come lavoro e come mercato", Nuova Corrente, 22, pp. 37-46 [Republished in Rossi-Landi 1968].

1966 "Presentation of 'La grammatica dell'algebra' by G. Vailati”, Nuova Corrente, 38, pp. 131-132.

1967a Entries [1964]: M. Calderoni, C. Cattaneo, E. Colorni, H. Dingler, F. Enriques, G. Peano, G. Vailati. In Encyclopedia of Philosophy, 8 vols., Paul Edwards (ed.), New York: MacMillan.

1967b 'Premessa' of three essays by C. Morris, Nuova Corrente, 42-43, pp. 113-117 [Republished in Rossi-Landi 1972 with the title "Sul modo in cui è stata fraintesa la semiotica estetica di Charles Morris"].

1968a "Editoriale: per un rinnovamento dell'elaborazione ideologica" (with M. Sabbatini), Ideologie 3, pp. 3-8. 


\section{Ocula ${ }^{16}$}

Semiotics of Economic Discourse | Semiotica del discorso economico

Cinzia Bianchi | Ferruccio Rossi-Landi: language, society and semiotics

1968b Il linguaggio come lavoro e come mercato, Milan: Bompiani [2nd ed. 1973, 3rd ed. 1983, 4th ed. 2003; English trans. see Rossi-Landi 1983].

1972 Semiotica e ideologia, Milan: Bompiani [2nd ed.1979, 3rd ed. 2007].

1973 Ideologies of Linguistic Relativity, The Hague: Mouton. [English trans. of Rossi-Landi 1972, chap. X].

1974a "Sul denaro linguistico", in AA.VV. Follia e società segregativa, Milan: Feltrinelli, pp. 96-123 [Convegno di studi, Milan December 13-16, 1973; republished in Rossi-Landi 1985; partial English trans. see Rossi-Landi 1980].

1974b “Articulations in verbal and objectual sign systems", Working Papers (Centro Internazionale di Semiotica e di Linguistica di Urbino) 38/39.

1974c Linguistics and Economics [1970-1971], The Hague: Mouton. Part eight of Volume XII: Linguistics and adjacent arts and sciences, of Current Trends in Linguistics [Published also as an indipendent volume; see Rossi-Landi 1975b].

1975a (ed.) [1964-1966], Scritti by Eugenio Colorni, Florence: La Nuova Italia.

1975b Linguistics and Economics (Janua Linguarum, Series Maior 81), The Hague: Mouton [Reproduces, with revisions and addition of indexes, 1974c].

1975c "Signs on a master of signs" [1973], Semiotica, 13 (2), pp. 155-197 [Revised and enlarged Italian trans. in 1975d].

1975d Charles Morris e la semiotica novecentesca, (Semiotica e pratica sociale 1), Milan: Feltrinelli-Bocca [Included 1953a and 1975c].

1977 "Introduction to Semiosis and Social Reproduction", Working Papers (Centro Internazionale di Semiotica e Linguistica di Urbino) 63.

1978a "Sign systems and social reproduction", Ideology and Consciousness 3, pp. 49-65.

1978b Ideologia Milan: ISEDI [Second revised, enlarged edition Milan: Mondadori 1982; 3rd ed. Rome: Meltemi 2005; English trans. see Rossi-Landi 1990].

$1978 \mathrm{c}$ "On the overlapping of categories in the social sciences" [1972], in AA.VV. Language and Thought. Anthropological Issues, The Hague: Mouton, pp. 391-403 [Ninth International Congress of Anthropological and Ethnological Sciences, Chicago, August-September 1973].

1978d “On some post-Morrisian problems", Ars semeiotica, 3, pp. 3-32.

1979a "On the dialectic of exogamic exchange" [1972], in AA.VV. Towards a Marxist Anthropology, The Hague: Mouton, pp. 141-150 [Ninth international Congress of Anthropological and Ethnological Sciences, Chicago, Aug.-Sept. 1973].

1979b "Signs and bodies" [1974], A Semiotic Landscape, The Hague: Mouton, pp. 356-359 [Paper presented at the First Congress of the International Association for Semiotic Studies, Milan, June, 1974].

1979c "Towards a theory of sign residues", Versus, 23, pp. 15-32 [Paper presented at the third Austrian Symposium of Semiotics, Vienna, August 1977].

1979d "Per la ristampa di un mio vecchio libro", Scienze umane, 2, pp. 147-167 [Republished as "Introduzione" of second edition of Rossi-Landi 1961].

1979e "Wittgenstein e l'alienazione", Scienze Umane, 1, pp. 135-145 [Paper presented at the Congress of Studies on Wittgenstein: 'Linguaggio e conoscenza come realtà sociale', Rome, January 1979].

$1979 f$ "Aspetti biologici e aspetti sociali del linguaggio nella loro interrelazione" (with M. Pesaresi), Scienze Umane, 3, pp. 37-96. [Republished in RossiLandi 1985; partial English trans. see Rossi-Landi 1981b].

1980 "On Linguistic Money", Philosophy and Social Criticism 3-4, pp. 347-372 [English trans. of Rossi-Landi 1974a].

1981a "Wittgenstein, old and new" [1979], in T. Belbo (ed.) Semiotics Unfolding, vol. 3, Berlin-New York-Amsterdam: Mouton, pp. 327-344. [Paper presented at the Second Congress of International Association for Semiotic Studies, Vienna, July 1979; republished in Ars semeiotica, 4 (1), pp. 29-51].

1981b "Language", in R. Williams (ed.), Contact: human communication and its history, London: Thames and Hudson Ltd, pp. 21-38 [English trans. of Rossi-Landi 1979f].

1983 Language as Work and Trade. A Semiotic Homology for Linguistic \& Economics, South Hadley (Mass.): Bergin and Garvey [English trans. of Rossi-Landi 1968b]. 


\section{Ocula ${ }^{16}$}

Semiotics of Economic Discourse | Semiotica del discorso economico

Cinzia Bianchi | Ferruccio Rossi-Landi: language, society and semiotics

1985 Metodica filosofica e scienza dei segni, Milan: Bompiani [2nd ed. 2006].

1986 "Semiosi e riproduzione sociale", Idee, 2-3, pp. 87-97.

1987 "La non-filosofia”, S. Petrilli (ed.), 1987a, pp. 191-194.

1988 "A fragment in the history of Italian semiotics", in M. Herzfeld and L. Melazzo (eds.), Semiotic Theory and Practice Berlin: Mouton de Gruyter, pp. 1053-1063. [Paper presented at the Third Congress of International Association for Semiotic Studies (Palermo, 1984)].

1990 Marxism and Ideology, Oxford: Clarendon Press [English trans. of RossiLandi 1978b].

1992 Between signs and non-signs, S. Petrilli (ed.), Amsterdam: John Benjamins.

1994 "Per il corso di Filosofia morale" [Università di Padova, 1959-60], Mario Quaranta (ed.), in J. Bernard, M.A. Bonfantini, J. Kelemen, A. Ponzio (eds.) 1994, pp. 39-58.

2002 "Il corpo del testo tra riproduzione sociale ed eccedenza. Dialogo" (1985), Susan Petrilli (ed.), Corposcritto, 2, pp. 7-43.

2003 Scritti su Gilbert Ryle e la filosofia analitica, C. Zorzella (ed. and introduction), Padova: Il Poligrafo.

Saussure, Ferdinand de

1916 Cours de linguistique générale, Paris: Editions Payot [English trans. as Course in General Linguistics, London: Peter Ower, 1960].

Strawson, Peter F.

1952 Introduction to Logical Theory, London: Methuen.

Vailati, Giovanni

1916 Gli strumenti della conoscenza, Lanciano: Carabba [M. Calderoni (ed.), collection of essays].

1957 Il metodo della filosofia, F. Rossi-Landi (ed.), Bari: Laterza [2nd ed. revisited 1967].

1966 "La grammatica dell'algebra" [1908], Nuova Corrente, 30, pp. 131-157.

Wittgenstein, Ludwig

1922 Tractatus logico-philosophicus [German text and English translation] London: Routledge \& Kegar Paul,1933.

1953 Philosophische Untersuchungen, [German text and English translation: Philosophical Investigations] Oxford: Basil Blackwell.

Zonzella, Cristina

2005 "La metodologia del parlare comune come scienza del linguaggio", Lingua e conoscenza. Janus. Quaderni del Circolo Glossematico, V, Padova: Il Poligrafo, pp.77-103. 